\title{
SYMBOLS AND SELECTIVITY: A STATISTICAL ANAL YSIS OF NATIVE AMERICAN MEDICAL ETHNOBOTANY
}

\section{DANIEL E. MOERMAN}

Department of Anthropology, University of Michigan-Dearborn, College of Arts, Sciences and Letters, 4901 Evergreen Road, Dearborn, MI 48128 (U.S.A.)

(Received July 27, 1978; accepted November 9, 1978)

\section{Summary}

Native Americans use a wide range of plants medicinally. Many of these plants have profound meaning to their users. Does this mean, as some assert, that tribal medicine is "all placebo"? Since the essential character of meaning is the arbitrariness of the sign, then insofar as this medicine is symbolic, the plants used medicinally will be a random representation of plants available in nature. Several regression analyses of plants used by native Americans on plants available to them indicate substantial selectivity in plant use. Native American medical ethnobotany is not only placebo medicine.

Many investigators over the past century have commented on the medical value of the native American pharmacopoeia. Yet anyone who has worked for long with the materials of ethnobotany occasionally finds himself confronting curious and disquieting anomalies. Consider the following items, culled from a large listing of native American medical ethnobotany (Moerman, 1977):

(1) While Pauite and Shoshone are reported to use a decoction of the root of Berberis repens (barberry) as an antidiarrheal (Train et al., 1941, p. 52), the Ramah Navaho use the same decoction as a laxative (Vestal, 1952, p. 28).

(2) While Creek Indians are reported to use a decoction of leaves of Gnaphalium oftusifolium (Everlasting) internally and externally as a sedative to help the elderly sleep (Swanton, 1928, p. 661), the Fox smudge the leaves of the plant to revive unconscious individuals (Smith, 1928, pp. 214-5).

(3) While Mohegan Indians reportedly used an infusion of blossoms of Humulus lupulus (hops) as a sedative to relieve nervous tension (Tantaquidgeon, 1972, p. 72), the Delaware of Oklahoma use a decoction of leaves of the same plant as a stimulant (Tantaquidgeon, 1942, p. 76).

(4) While Pauite Indians reportedly use a decoction of Lygodesmia spinosa (Indian gum plant) as an emetic (Train et al., 1941, pp. $102-3$ ), the 
neighboring Shoshone are reported by the same authors to use the same medication as an antiemetic (ibid., pp. $102-3$ ).

More similar cases could be cited. Recognizing that the part of the plant used, the way it is prepared, the dosage, the length of administration, and other matters greatly affect the physiological activity of plant drugs only marginally diminishes our concern that these cases indicate that the pharmacology of the medication might be a secondary matter in native therapy.

We are all aware that the conceptualizations of doctors and patients are important factors in the effectiveness of any medical or surgical procedure. The pervasive placebo effect, which encumbers biomedicine with the necessity of double blind procedures, is a powerful human force (for a recent review of the theoretical and philosophical implications of such forms of symbolic healing, see Moerman, 1979).

Our awareness of these symbolic factors in medicine, coupled with the recognition of anomalies like those listed above, suggest a disconcerting hypothesis, that native American medicine is substantially based on general factors, is "all placebo". Some authors flatly assert this; Adler and Hammet, for instance, note "it is generally agreed that the history of medicine up until the last $100-150$ years has been the history of this pervasive placebo effect" (Adler and Hammet, 1973, p. 595).

Counter arguments can, of course, be easily made by showing, through pharmacological trials, that certain tribal medications do have appropriate therapeutic action. Solecki's famous account of Middle Paleolithic medicinal plants at Shanidar is a helpful case (Solecki, 1975).

I propose an additional approach to the problem. Were native American medicine "all placebo", then the medications used (primarily botanicals) would be used because of their "meanings" or their "symbolic values". Since the essential character of "meaning" is the arbitrariness of symbol, it seems reasonable to assert that, insofar as native American medicine is "symbolic", the plants used medicinally will be a random representation of plants in nature. This paper will report a test of that hypothesis.

Data come primarily from two sources. Medical information comes from a computerized database of native American Medical Ethnobotany (AME). Included in this database are 1288 different plant species from 531 different genera and 118 different families used medically by 48 different cultures in 4869 different ways (Moerman, 1977). Botanical information comes from another computerized database, the Species Name List of Flora North America (FNA) which lists 16270 species from 2352 genera in 232 families*. A published version of this list has just appeared under the title

*The FNA Checklist was manipulated to obtain a list of numbers of genera and species per family for North America and four selected regions. These data, and data for the remaining 13 regions coded in FNA will be published separately. These data are, of course, provisional; but since taxonomy is as much art as science, it seems unlikely that, short of major changes in the contemporary approach to classification, substantial shifts in these varying generic and specific frequencies are in the offing. 
A Provisional Checklist of Species for Flora North America (Shetler and Skog, 1978). By appropriate manipulation of these two databases, the author was able to test the hypothesis that, in North America as a whole, and in four selected North American regions (North Central, Southwest, Intermountain, and Western Canada), the number of genera and species per family present in the region according to FNA could account for the number of items from that family in AME (see Table 1). The statistical model used was multiple linear regression. A regression model tests the hypothesis that there is a functional relationship between two variables. If medicinal use is a function of generic and specific availability, a regression would show a "cloud" of experimental values to be randomly distributed about the regression line.

TABLE 1

Regional characteristics

\begin{tabular}{|c|c|c|c|c|}
\hline \multirow[t]{2}{*}{ Region } & \multicolumn{2}{|l|}{ FNA } & \multicolumn{2}{|l|}{ AME } \\
\hline & Genera & Species & Tribes & Items \\
\hline \multirow[t]{6}{*}{$\mathrm{NC}$} & 987 & 3387 & Chippewa & 343 \\
\hline & & & Menominee & 222 \\
\hline & & & Ojibwa & 231 \\
\hline & & & Potawatomi & 190 \\
\hline & & & Winnebago & 37 \\
\hline & & & & 1023 \\
\hline \multirow[t]{6}{*}{ SW } & 1011 & 5022 & Hopi & 105 \\
\hline & & & Keresan & 5 \\
\hline & & & Ramah Navaho & 560 \\
\hline & & & Tewa & 39 \\
\hline & & & Zuni & 99 \\
\hline & & & & 808 \\
\hline \multirow[t]{6}{*}{$\mathrm{IM}$} & 876 & 4110 & Paiute & 487 \\
\hline & & & Papago & 17 \\
\hline & & & Pima & 20 \\
\hline & & & Shoshone & 485 \\
\hline & & & Washoe & 56 \\
\hline & & & & 1056 \\
\hline \multirow[t]{9}{*}{ WC } & 675 & 2565 & Bella Coola & 125 \\
\hline & & & Gitksan & 70 \\
\hline & & & Kwakiutl & 17 \\
\hline & & & N. Carrier & 23 \\
\hline & & & Nootka & 6 \\
\hline & & & S. Carrier & 33 \\
\hline & & & Thompson & 206 \\
\hline & & & Tlingit & 21 \\
\hline & & & & 501 \\
\hline
\end{tabular}


In the five selected regions, the number of AME items per family was regressed on the number of FNA genera and species per family (see Table 2 ). The results of these regressions are quite variable. Multiple correlation $(r)$ varies from a high of 0.854 in the Southwest to a low of 0.445 in Western Canada, while for all of North America the figure is 0.781 . The coefficient of determination $\left(r^{2}\right)$ for North America is 0.611 ; this can be read as saying that $61 \%$ of the variance in the number of genera used medicinally per family can be explained by the number of available genera and species per family.

TABLE 2

Multiple regressions: number of medicinal items per family regressed on number of genera and number of species, for North America and four selected regions ( $N=232$ in each case)

\begin{tabular}{|c|c|c|c|c|c|c|c|}
\hline \multirow[t]{2}{*}{ Region } & \multirow{2}{*}{$\begin{array}{l}\text { Multiple } \\
\text { correlation } \\
(r)\end{array}$} & \multirow{2}{*}{$\begin{array}{l}\text { Coef. of } \\
\text { determination } \\
\left(r^{2}\right)\end{array}$} & \multirow[t]{2}{*}{ Constant } & \multicolumn{2}{|c|}{ Regression coefficients } & \multicolumn{2}{|c|}{ Residuals } \\
\hline & & & & Genera & Species & $S^{*}$ & $K^{* *}$ \\
\hline NA & 0.781 & 0.611 & 0.428 & 1.025 & 0.143 & 0.275 & 38.457 \\
\hline NC & 0.694 & 0.421 & 1.15 & 0.327 & 0.131 & 1.297 & 26.329 \\
\hline SW & 0.854 & 0.730 & -1.22 & 1.59 & -0.134 & -1.876 & 51.998 \\
\hline $\mathbf{I M}$ & 0.805 & 0.648 & -0.652 & 1.074 & 0.0689 & -0.741 & 34.107 \\
\hline wC & 0.445 & 0.198 & 0.922 & 0.296 & 0.0293 & 6.528 & 62.028 \\
\hline
\end{tabular}

* Skewness. **Kurotsis.

A regression model, however, requires that error be randomly distributed about the regression function. Examination of residuals showed that they were not so distributed as a number of cases fell well away from predicted values. These values represent families which are used much more, or much less, than availability would predict; in other words, these values represent families in which selectivity is apparent. An attempt was then made to sort out these highly selected families, and to re-examine those remaining.

To do this, families were sorted into strata as a function of the number of standard deviations by which observed medicinal uses differed from predicted uses. Stratum 1 included all plant families with residuals two standard deviations below predicted value, stratum 2 all those between one and two standard deviations below predicted value, stratum 3 all those within one standard deviation of the predicted value; strata 4 and 5 match strata 1 and 2 above the mean. In this way, plant families with usage above and below that level which would be predicted by generic and specific availability could be identified; alternatively, this technique identified those families in which substantial selectivity in usage (positive or negative) was indicated. Table 3 lists two groups of plant families, those used much more or much less frequently than one would predict on the basis of generic and specific availability.

These data were then put to another test. The families which indicated substantial selectivity were deleted from the sample, and the regressions were repeated (see Table 4). In four of five regions, this procedure "improved" 
TABLE 3

\begin{tabular}{|c|c|c|c|c|c|c|}
\hline \multirow[t]{2}{*}{ Family } & \multicolumn{5}{|c|}{ Strata (see text) } & \multirow[t]{2}{*}{ Mean } \\
\hline & NA & $\mathrm{NC}$ & SW & $\mathbf{I M}$ & WC & \\
\hline \multicolumn{7}{|l|}{ High use families } \\
\hline Pinaceae & 5 & 5 & 5 & 5 & 5 & 5 \\
\hline Asteraceae & 5 & 5 & 5 & 5 & 3 & 4.6 \\
\hline Rosaceae & 5 & 5 & 3 & 5 & 5 & 4.6 \\
\hline Polygonaceae & 4 & 3 & 5 & 5 & 3 & 4 \\
\hline Araliaceae & 4 & 4 & 3 & 3 & 5 & 3.8 \\
\hline Betulaceae & 4 & 5 & 3 & 3 & 4 & 3.8 \\
\hline Caprifoliaceae & 4 & 4 & 3 & 3 & 5 & 3.8 \\
\hline Araceae & 4 & 5 & 3 & 3 & 3 & 3.6 \\
\hline Liliaceae & 3 & 5 & 2 & 3 & 5 & 3.6 \\
\hline Ranunculaceae & 4 & 4 & 3 & 3 & 4 & 3.6 \\
\hline Apiaceae & 4 & 3 & 1 & 5 & 4 & 3.4 \\
\hline Lamiaceae & 4 & 3 & 3 & 4 & 3 & 3.4 \\
\hline Polygonaceae & 3 & 3 & 4 & 4 & 3 & 3.4 \\
\hline Salicaceae & 4 & 4 & 3 & 3 & 3 & 3.4 \\
\hline Anacardiaceae & 3 & 4 & 3 & 3 & 3 & 3.2 \\
\hline Apocynaceae & 3 & 4 & 3 & 3 & 3 & 3.2 \\
\hline Cornaceae & 3 & 4 & 3 & 3 & 3 & 3.2 \\
\hline Ephedraceae & 3 & 3 & 3 & 4 & 3 & 3.2 \\
\hline Ericaceae & 3 & 3 & 3 & 3 & 4 & 3.2 \\
\hline Euphorbiaceae & 3 & 3 & 4 & 3 & 3 & 3.2 \\
\hline Solanaceae & 3 & 3 & 4 & 3 & 3 & 3.2 \\
\hline \multicolumn{7}{|l|}{ Low use families } \\
\hline Onagraceae & 3 & 3 & 4 & 2 & 3 & 3.0 \\
\hline Acanthaceae & 3 & 3 & 2 & 3 & 3 & 2.8 \\
\hline Chenopodiaceae & 3 & 3 & 3 & 2 & 3 & 2.8 \\
\hline Cucurbitaceae & 3 & 3 & 2 & 3 & 3 & 2.8 \\
\hline Boraginaceae & 3 & 3 & 3 & 2 & 2 & 2.6 \\
\hline Orchidaceae & 2 & 3 & 2 & 3 & 3 & 2.6 \\
\hline Polypodiaceae & 3 & 3 & 2 & 2 & 3 & 2.6 \\
\hline Caryophyllaceae & 2 & 2 & 3 & 2 & 2 & 2.2 \\
\hline Fabaceae & 1 & 2 & 3 & 2 & 2 & 2 \\
\hline Brassicaceae & 2 & 1 & 3 & 1 & 2 & 1.8 \\
\hline Cyperaceae & 1 & 1 & 3 & 1 & 2 & 1.8 \\
\hline Poaceae & 1 & 1 & 1 & 1 & 1 & 1 \\
\hline
\end{tabular}

the regression results, particularly for Western Canada, where $r$ increased from 0.445 to 0.893 . In the Intermountain region, the correlation dropped slightly from 0.805 to 0.777 . In all cases, the residuals assumed a more normal distribution. Kurtosis dropped at least by a factor of 6 in all cases. But these residuals are by no means yet in a random distribution. We infer that substantial selectivity continues to be in evidence, even after reducing sample size by deleting those families showing the most selectivity.

To test the hypothesis in another way, a similar stratifying procedure was used on the entire North American sample for which figures were available for the actual numbers of genera and species with medicinal uses per family. Single regressions were calculated for medicinal genera on 


\section{TABLE 4}

Multiple regressions: number of medicinal items per family regressed on number of genera and number of species per family, for North America and four selected regions, deleting families showing substantial selectivity

\begin{tabular}{|c|c|c|c|c|c|c|c|c|}
\hline \multirow[t]{2}{*}{ Region } & \multirow[t]{2}{*}{$n$} & \multirow{2}{*}{$\begin{array}{l}\text { Multiple } \\
\text { correlation } \\
(r)\end{array}$} & \multirow{2}{*}{$\begin{array}{l}\text { Coef. of } \\
\text { determination } \\
\left(r^{2}\right)\end{array}$} & \multirow[t]{2}{*}{ Constant } & \multicolumn{2}{|c|}{ Regression coefficients } & \multicolumn{2}{|c|}{ Residuals } \\
\hline & & & & & Generá & Species & $S^{*}$ & $K^{* *}$ \\
\hline NA & 214 & 0.815 & 0.664 & 0.699 & 0.547 & 0.140 & 1.679 & 6.321 \\
\hline NC & 214 & 0.802 & 0.643 & -0.032 & 0.481 & 0.104 & 0.830 & 3.233 \\
\hline SW & 218 & 0.925 & 0.855 & 0.571 & 1.055 & -0.052 & 0.338 & 4.846 \\
\hline IM & 215 & 0.777 & 0.604 & -0.243 & 0.708 & 0.082 & 1.990 & 7.317 \\
\hline WC & 216 & 0.893 & 0.798 & 0.068 & 0.188 & 0.076 & 2.219 & 9.369 \\
\hline
\end{tabular}

*Skewness. **Kurtosis.

available genera, and medicinal species on available species; in both cases correlations were high, 0.895 and 0.849 respectively. The first case was selected for further analysis. Examination of residuals showed a highly "spiked" distribution (kurtosis = 59.7), mean of zero, and modest skewing (skewness $=-3.97$ ). Families showing substantial "error", that is, positive or negative selectivity relative to availability, were deleted from the sample, and the remaining cases were again subjected to regression. Cases were dropped in which the actual value departed from the predicted value by more (or less) than the value of the standard error in the previous regression. Following each regression, the distribution of the reduced number of residuals was examined, families with residuals greater than one standard error were dropped, and the regression was repeated. By the third iteration, residual distribution began to approximate more closely a normal distribution. Sample size was by then 210 (from 232), nean was zero, skewness was reduced to 0.296 , kurtosis to 0.174 . While residuals formed a ragged bell shape, $67 \%$ of cases fell within one standard deviation of the mean, and $95 \%$ within two. Statistics for these three regressions (plus a fourth) appear in Table 5. The

\section{TABLE 5}

Successive regressions of medicinal genera on available genera, dropping cases with substantial error

\begin{tabular}{|c|c|c|c|c|c|c|c|}
\hline \multirow[t]{2}{*}{ Case } & \multirow[t]{2}{*}{$n$} & \multirow[t]{2}{*}{$r$} & \multirow{2}{*}{$\begin{array}{l}\text { Standard } \\
\text { error of } \\
\text { regression }\end{array}$} & \multicolumn{4}{|c|}{ Residuals } \\
\hline & & & & Min. & Max. & Skewness & Kurtosis \\
\hline 1 & 232 & 0.89456 & 8.6059 & -31.237 & 15.196 & -3.973 & 59.693 \\
\hline 2 & 228 & 0.91952 & 2.1799 & -8.4393 & 8.4393 & 0.254 & 10.402 \\
\hline 3 & 210 & 0.92132 & 0.69697 & -1.9053 & 2.2203 & 0.296 & 0.174 \\
\hline 4 & 134 & 0.96573 & 0.0926 & -0.4719 & 0.74652 & 1.059 & 0.990 \\
\hline
\end{tabular}


twenty-two plant families deleted in the first three iterations are listed in Table 6. The 76 families ( 31 "low use", 45 "high use") dropped for the last iteration are not listed.

\section{Discussion}

There are obviously a number of substantial methodological flaws in this paper. Ethnological data on which AME is based were gathered by many investigators, some with dubious botanical qualification, over a period of 80 years; many of their identifications are probably suspect. Many botanists would disagree with aspects of the taxonomy in FNA. Moreover, the presence of plants representing a taxon in a region is not a very precise measure of their availability (e.g., compare the availability in the Great Lakes area of Taraxacum officinale with, say, that of Malaxis paludosa). Again, if for half of the North American plant families medicinal usage approximates availability, this may be because medicinal value is randomly distributed among the taxa of these families.

Yet this approach yields dividends. While general knowledge of ethnobotany would surely pick out Asteraceae and Rosaceae as worthy of special notice, it seems less obvious to identify Caprifoliaceae, with its 7 genera and 77 species, as a particularly "medicinal" family; yet all seven genera are used medicinally ( 105 ways) by the AME sample of cultures.

\section{TABLE 6}

Highest and lowest use families identified by subsequent regressions of medicinal genera on available genera

\begin{tabular}{|c|c|c|c|c|}
\hline \multirow[t]{2}{*}{ Iteration } & \multicolumn{2}{|l|}{ High use } & \multicolumn{2}{|l|}{ Low use } \\
\hline & Family & Residual* & Family & Residual* \\
\hline 1 & $\begin{array}{l}\text { Asteraceae } \\
\text { Rosaceae } \\
\text { Ranunculaceae }\end{array}$ & $\begin{array}{c}15.169 \\
13.491 \\
8.7531\end{array}$ & Poaceae & -31.237 \\
\hline 2 & $\begin{array}{l}\text { Pinaceae } \\
\text { Fabaceae } \\
\text { Caprifoliaceae } \\
\text { Lamiaceae } \\
\text { Liliaceae } \\
\text { Apiaceae } \\
\text { Polemoniaceae } \\
\text { Chenopodiaceae } \\
\text { Betulaceae } \\
\text { Berberidaceae } \\
\text { Pyrolaceae }\end{array}$ & $\begin{array}{l}8.3955 \\
7.4955 \\
5.3955 \\
4.8450 \\
4.1991 \\
3.8928 \\
3.6729 \\
2.9504 \\
2.8261 \\
2.3955 \\
2.3189\end{array}$ & $\begin{array}{l}\text { Orchidaceae } \\
\text { Acanthaceae } \\
\text { Caryophyllaceae } \\
\text { Rubiaceae } \\
\text { Sapindaceae } \\
\text { Myrticaceae } \\
\text { Scrophulariaceae }\end{array}$ & $\begin{array}{l}-7.5856 \\
-4.1883 \\
-3.6334 \\
-3.2027 \\
-2.6811 \\
-2.2505 \\
-1.3081\end{array}$ \\
\hline
\end{tabular}

*On initial regression. 
Also of interest is the number of "low use" families from Table 3 which contain widely used food species: Poaceae (Gramineae), Brassicaceae (Cruciferae), Fabaceae (Leguminosae), Cucurbitaceae, and Chenopodiaceae are all families of widely used food plants. While some families in the "high use" portion of Table 3 provide edibles (sunflower seeds, pine nuts), most do not. Food and medicine appear by this analysis to be substantially discontinuous categories.

\section{Conclusions}

It is clear that much of medicine (ethno- or otherwise) is symbolic, based on meaning and placebo. But these data indicate substantial selectivity in the medical use of natural species by native American peoples. The three highest use families from Table 6 (Asteraceae, Rosaceae, Ranunculaceae) account for $29 \%$ of medicinal items in AME, but $15.9 \%$ of genera in FNA, while the three lowest use families from that Table (Poaceae, Orchidaceae, Acanthaceae) account for $1.2 \%$ of items in AME, but $12 \%$ of genera in FNA. Evidently, native American medical ethnobotany was not "only placebo medicine".

\section{Acknowledgements}

This paper could not have been written had the author not had access to the computerized record of the Flora North America (FNA) Checklist, generously provided by Stanwyn $G$. Shetler of the Smithsonian Institution National Museum of Natural History. The FNA material was converted to a file using the TAXIR (taxonomic information retrieval) program maintained by the University of Michigan Computing Centers. The American Medical Ethnobotany (AME) database is also stored in a TAXIR file. Robert C. Brill of the UM Computing Center provided invaluable counsel in using TAXIR, reprogramming on occasion to meet special needs. Statistical calculations were made with the University of Michigan Statistical Research Laboratory Michigan Interactive Data Analysis System (MIDAS); Kenneth E. Guire of the Statistical Research Laboratory provided statistical guidance and general encouragement. The University of Michigan-Dearborn College of Arts, Sciences and Letters provided computer funds.

\section{References}

Adler, H. M. and Hammett, V. O., The doctor-patient relationship revisited : an analysis of the placebo effect, Ann. Intern. Med., 78 (1973) $595 \cdot 598$.

Moerman, D. E., American Medical Ethnobotany: A Reference Directory, Garland, New York, 1973.

Moerman, D. E., The anthropology of symbolic healing, Curr. Anthropol., (1979), in press. 
Shetler, Stanwyn G. and Skog, L. E., (eds.), A Provisional Checklist of Species for Flora North America (Revised), Monographs in Systematic Botany, Vol. 1, Missouri Botanical Garden, St. Louis (Flora North America Report 84), 1978.

Smith, H. H., Ethnobotany of the Meskwaki Indians, Bull. Public Mus. Milwaukee, 4 (1928) $175 \cdot 326$.

Solecki, R. S., Shanidar IV, A Neanderthal burial in northern Iraq, Science, 190 (1975) $880-81$.

Swanton, J. R., Religious beliefs and medical practices of Creek Indians, 42 nd Ann. Rep. Bureau of A merican Ethnology, 1928, pp. $473-462$.

Tantaquidgeon, G., A Study of Delaware Indian Medicine Practice and Folk Belief, Pennsylvania Historical Commission, Harrisburg, 1942.

Tantaquidgeon, G., Folk Medicine of the Delaware and Related Algonkian Indians. Papers of the Pennsylvania Historical and Museum Commission \#3, 1972.

Train, P., Herrichs, J. R. and Archer, W. A., Medicinal Uses of Plants by Indian Tribes of Nevada. Contributions to a Flora of Nevada \#33. USDA, Washington, DC, 1941.

Vestal, P. A., The Ethnobotany of the Ramah Navaho. Papers of the Peabody Museum of American Archeology and Ethnology $\# 40: 4,1952$. 